\title{
Analysis of the Effectiveness of Long Distance Passes in 2014 Brazil FIFA World Cup
}

\section{Análise da Eficácia dos passes de longa distância na Copa do Mundo FIFA Brasil 2014}

Marcos Antônio Mattos dos Reis ${ }^{1}$

Fabrício Vieira do Amaral Vasconcellos²

Marcos Bezerra de Almeida ${ }^{1}$

\begin{abstract}
The aim of this study was to analyze the effectiveness of long distance passes performed during the 2014 Brazil FIFA World Cup. All 64 matches were analyzed, however, actions performed during overtime were not included in the sample. The study defined long pass as an action made by a player from the defensive midfield aiming at passing the ball to another teammate located on the offensive field. The action result assessment followed these criteria: shots on goal, ball possession maintenance, loss of ball possession and ball possession recovery. Total long distance passes were also considered in the analysis. Throughout the tournament, 4,512 long distance passes were attempted. The main findings were that $59 \%$ resulted on loss, $28 \%$ on maintenance and $12 \%$ on recovery of the ball possession, but only less than $1 \%$ resulted in shots on goal $(\mathrm{F}=$ 505.5; $\mathrm{p}<0.001$; partial $\eta^{2}=0.76$ ). Teams with the highest number of long pass attempts loose ball possession more frequently. There were more long distance passes at the first and at the last $15 \mathrm{~min}$ of matches. UEFA and Concacaf teams executed, respectively, the lowest and the highest number of long passes. The major outcome of this study is that long distance passes have low effectiveness due to the high rate of loss of ball possession, rarely creating score opportunities. The more the teams executed long passes, the more the teams lose ball possession.
\end{abstract}

Key words: Observational study; Performance; Soccer.

Resumo - Objetivou-se analisar a eficácia dos passes de longa distância realizados durante os jogos da Copa do Mundo da FIFA 2014. Todas as 64 partidas foram analisadas. Porém, as prorrogações na fase eliminatória da competição não foram acrescidas na amostra. O estudo definiu o lançamento como uma ação feita por um jogador do meio campo defensivo com o objetivo de passar a bola para outro colega de equipe localizado no campo ofensivo. O resultado da ação foi avaliado com base nos seguintes critérios: finalização ao gol, manutenção da posse de bola, perda da posse de bola e recuperação da posse de bola. O total dos lançamentos também foi considerado nas análises. Ao longo do torneio houve 4.512 lançamentos. Os principais achados foram que 59\% dos lançamentos resultaram em perda, $28 \%$ em manutenção e $12 \%$ em recuperação da posse da bola, mas apenas menos de $1 \%$ resultaram em finalização ao gol $(F=505,5$; $p$ $<0,001$ Parcial $\left.\eta^{2}=0,76\right)$. Equipes que lançaram mais perderam a bola com maior frequência. Houve mais lançamentos nos primeiros e nos últimos 15 min de jogo. Equipes da UEFA e da Concacaf executaram, respectivamente, o mais baixo e o mais alto número de lançamentos. $O$ principal achado deste estudo é que os lançamentos apresentam baixa eficácia devido à alta taxa de perda da posse de bola, raramente criando oportunidades de finalização à meta. Quanto mais lançamentos feitos, mais posse de bola perdida.

Palavras-chave: Desempenho; Estudo observacional; Futebol.
1 Federal University of Sergipe. Laboratory of Study and Research in Performance in Exercise and Sport. Graduate Program in Physical Education. São Cristóvão, SE. Brazil.

2 University of the State of Rio de Janeiro. Laboratory of Soccer Studies. Graduate Program in Exercise and Sport Sciences. Rio de Janeiro, RJ. Brazil.

Received: 18 March 2017 Accepted: 18 October 2017 


\section{INTRODUCTION}

Knowledge from soccer game analyses has increased dramatically in recent years $^{1}$ as studies have investigated tactical principles, namely, general, operational and fundamental principles ${ }^{2,3}$. Their aim has been to clarify how teams create shots on goal, advance towards the opposite team's field, regain possession of the ball, protect their own goal, and maintain ball possession ${ }^{4}$. Currently, one of the most investigated principles has been maintenance of ball possession, and how this occurs, i.e., through long or short passes and the direction and speed of passes ${ }^{5}$.

Contemporary soccer is characterized by different changes in play patterns, especially in the last three decades, in which $31.4 \%$ of actions related to the internal logic of the game have changed ${ }^{6}$. Lately, teams have adopted a more direct game style, characterized by decreased ball driving and increased long distance passes ${ }^{6,7}$. However, while long distance passes were favored for scoring goals in the $1960 \mathrm{~s}^{8}$, their goal scoring success have seemed less likely more recently ${ }^{9}$.

Obviously, the performance of a soccer team is influenced by many different factors related to tactical and technical actions carried out during a game ${ }^{10-14}$. Still, to our best knowledge, scientific evidence supporting the effectiveness of long distance passes in contemporary high-level soccer is scarce. Considering that such technical action has been poorly investigated but often performed in games, it is important to conduct performance analyses and contribute to knowledge in this area.

Therefore, the aim of this study was to analyze the effectiveness of long distance passes performed during 2014 Brazil FIFA World Cup as stratified by: a) total number of long distance passes performed; b) elapsed match time; and c) Continental Federation association.

\section{METHODOLOGICAL PROCEDURES}

The Ethics Research Committee of Federal University of Sergipe approved the study, and all the procedures followed Brazilian CNS 466/2012 resolution (report $\left.n^{\circ} 1.060 .543 / 2015\right)$. All matches performed during the 2014 Brazil FIFA World Cup are available on Youtube social media website and therefore were included in the study. The sample included all 64 matches, and the actions exclusively performed within the 90-minute regular time (and the pertaining stoppage times) were considered. Thus, actions performed during extra time were not included in the sample.

Matches were fully recorded for further analysis. The decoupage of recordings was made using a spreadsheet where data such as elapsed game time, location and result of the action were entered. The behavior in collective sports occurs in interaction, for example the soccer, in this way game analysis becomes an important tool in order to check game patterns ${ }^{15}$. Long pass was defined as a technical action performed by a player from the defensive midfield, aiming at passing the ball to another teammate located on the offensive field (longitudinal axis) (figure 1). 


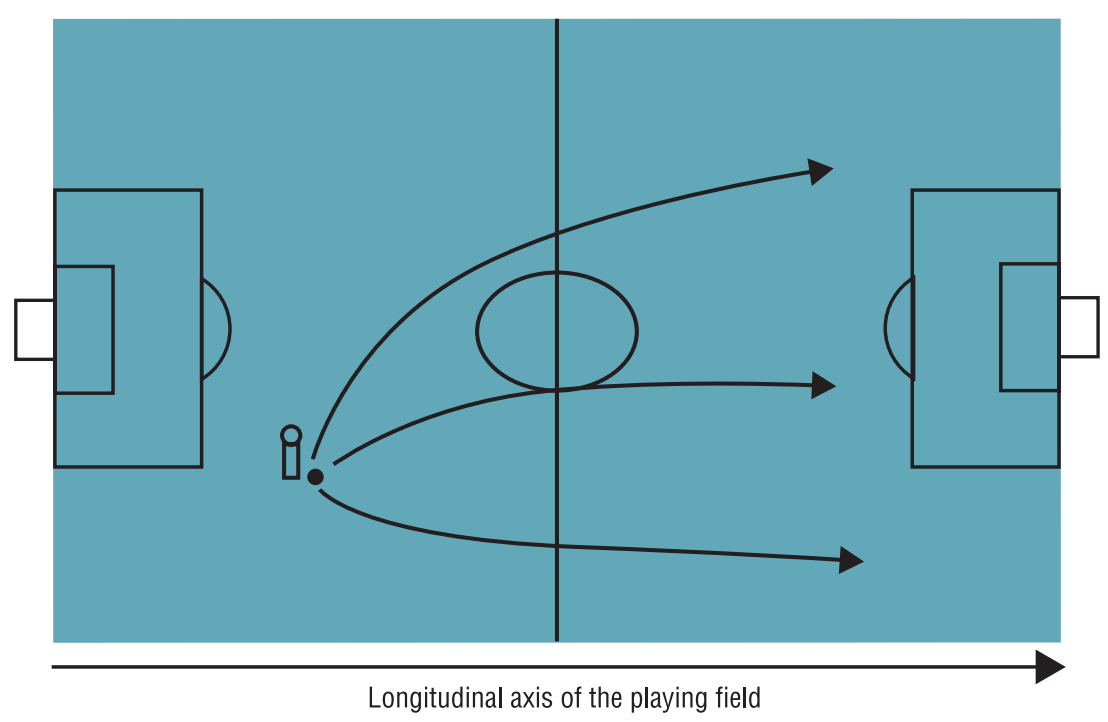

Figure 1. Characterization of long distance passes on the longitudinal axis of the playing field.

The operational tactical principles proposed by Bayer ${ }^{16}$ were used as indicators of the action result: "Ball possession maintenance (MBP)", "Shots on Goal" (SG) and "Ball possession recovery" (BPR). Additionally, one more criterion was established: loss of ball possession (LBP). LBP was considered as a change of ball possession after a long pass if an opponent stole the ball, ball went out of bounds or fouls and offside calls from the offensive team ${ }^{3}$. Total long distance passes (TP) were also considered in the analysis.

MBP and BPR principles were based on Costa et al. ${ }^{17}$, assuming that a team retains ball possession: a) when ball has at least three consecutive touches, individually or collectively; and b) when the team performs a positive pass. A positive pass occurs when the player with the ball passes the ball to his teammate, who is able to control it and move along with the play.

$\mathrm{BPR}$ was considered when team A performed a long pass and team $\mathrm{B}$ gained ball possession (up to three touches) and, following that, team $\mathrm{A}$ recovered ball possession. SG was defined as a field goal (made or attempt) performed between long pass reception and up to three touches made by the same player.

To assess intra-rater reliability, the same evaluator replicated the analysis on seven matches ( $10 \%$ of the sample), randomly selected, within 30 days apart. Reliability was determined by Cohen's Kappa coefficient and showed high agreement rate $(\mathrm{K} \text { index }=0.92 ; \mathrm{p}<0.001)^{18}$.

Comparisons were made through parametric test Analysis of Variance (ANOVA), followed by Tukey post-hoc test when appropriate for normal data (Kolmogorov-Smirnov test: $p>0.05$ ), and through non-parametric Kruskal-Wallis test, followed by Dunnett's C post-hoc test (if appropriate) when data failed normality. All calculations were made using the SPSS 20.0 statistical software (IBM, EUA) at significance level of 5\%.

Analysis also used Cohen's d effect size ${ }^{19}$ for two groups comparisons (Tukey and Dunnet's $C$ post hoc analysis) and partial $\eta^{220}$ for more than two groups comparisons (ANOVA and Kruskal-Wallis). Cohen classifies 
effect size as small $(\mathrm{d} \leq 0.2)$ medium $(\mathrm{d}=0.5)$, and large $(\mathrm{d} \geq 0.8)$, whereas the partial $\eta^{2}$ ranges from 0 to 1.0 , with the higher $\eta^{2}$ value, the higher effect size ${ }^{20}$.

Stratified analysis was based on the following criteria: a) teams were ranked according to the average number of long distance passes per match and stratified into quartiles (first quartile - Q1: lower number of long distance passes); b) match duration (regular time of $90 \mathrm{~min}$ ) was divided into 15-min blocks, creating six groups representing first or second period, and 15,30 or $45 \mathrm{~min}$ of elapsed time $(1 \mathrm{P} 15,1 \mathrm{P} 30,1 \mathrm{P} 45,2 \mathrm{P} 15,2 \mathrm{P} 30$, 2P45); and c) the Continental Federations to which teams were associated (Europe: UEFA; South America: Conmebol; Central and North America: Concacaf; Asia: AFC, and Africa: CAF).

Additionally, the percentage of shots on goal was identified in relation to the total goal kicks performed by each team/match. Data on total goal kicks were extracted from match reports available on the official website ${ }^{21}$ of the competition.

\section{RESULTS}

A total of 4,512 long distance passes were analyzed, in which teams lost ball possession in $59 \%$ of the tries, kept possession in $28 \%$, recovered ball possession in around $12 \%$ of the actions, and just less than $1 \%$ of passes resulted in shots on goal. There were statistical differences among the long passes outcomes $\left(\mathrm{F}(4,635)=505.5 ; p<0.001 ;\right.$ partial $\left.\eta^{2}=0.76\right)$, with a large effect size for all comparisons (table 1 ). The comparison with the total goal kicks attempted during the World Cup showed that only $1.83 \%$ of 1,690 kicks performed (including extra times) stemmed from long distance passes.

\section{Long Distance Passes per Game Ranking Analysis}

Teams in Q1 were less successful in maintaining ball possession when compared to the other teams. On the other hand, Q4 showed higher percentage of LBP. Only intermediate quartiles showed no significant difference among teams (SG: $\mathrm{F}(3,2)=1.4 ; p=0.25$; partial $\eta^{2}=0.04$ MBP: $\mathrm{F}(3,163)=9.5 ; p<0.001 ;$ partial $\eta^{2}=0.45 ; \operatorname{LBP}: \mathrm{F}(3,113)=52.1 ; p$ $<0.001$; partial $\eta^{2}=0.83$; BPR: F $(3,82)=1.6 ; p=0.20$; partial $\eta^{2}=0.06$; TP: $F(3,194)=81.5 ; p<0.001 ;$ partial $\left.\eta^{2}=0.89\right)$ (figure 2).

Table 1. Absolute values of long distance passes and their results in the 2014 Brazil FIFA World Cup p-value, $95 \% \mathrm{Cl}, \mathrm{partial} \eta^{2}$ and Cohen's d effect size.

\begin{tabular}{|c|c|c|c|c|c|c|c|}
\hline & $S G$ & MBP & LBP & BPR & TP & Partial $\eta^{2}$ & $p$ \\
\hline$n$ & 31 & 1258 & 2665 & 558 & 4512 & \multirow{4}{*}{0.76} & \multirow{4}{*}{$<0.01$} \\
\hline Mean $\pm S D$ & $0.2 \pm 0.5^{\star}$ & $9.8 \pm 5.4^{\star *}$ & $20.8 \pm 8.0 \dagger$ & $4.4 \pm 3.3 \dagger \dagger$ & $35.3 \pm 12.2$ & & \\
\hline Min. to Max. & 0 to 2 & 0 to 23 & 5 to 40 & 0 to 14 & 9 to 63 & & \\
\hline $95 \% \mathrm{Cl}$ & 0.2 to 0.3 & 8.9 to 10.8 & 19.4 to 22.2 & 3.8 to 4.9 & 33.1 to 37.4 & & \\
\hline
\end{tabular}

SG: shots on goal; MBP: maintenance of ball possession; LBP: Ioss of ball possession; BPR: ball possession recovery; TP: total long passes. ${ }^{*} p<0.001$ compared to MBP (CI 95\% = -10.9 to $\left.-8.3 ; d=3.3\right)$; LBP $(95 \% \mathrm{Cl}=-22.5$ to $-18.6 ; d=4.9) ; B P R(95 \% C l=-4.9$ to -3.3 ; $\mathrm{d}=2.2)$; and TP $(95 \% \mathrm{Cl}=-38.0$ to $-32.0 ; \mathrm{d}=5.5)$. ${ }^{* *} \mathrm{p}<0.001$ compared to LBP $(\mathrm{Cl} 95 \%=-13.4$ to $-8.6 ; \mathrm{d}=1.6) ; \mathrm{BPR}(95 \% \mathrm{Cl}=3.9$ to $7.0 ; d=1.3)$; and TP $(95 \% \mathrm{Cl}=-28.7$ to $-22.2 ; d=2.9)$. $\nmid p<0.001$ compared to $\mathrm{BPR}(95 \% \mathrm{Cl}=14.3$ to $18.6 ; d=2.9) ;$ and $\mathrm{TP}(95 \% \mathrm{Cl}=$ -18.0 to $-10.9 ; d=1.4)$. $\dagger \dagger p<0.001$ compared to TP $(C \mid 95 \%=-34.0$ to $-27.8 ; d=4.0)$. 


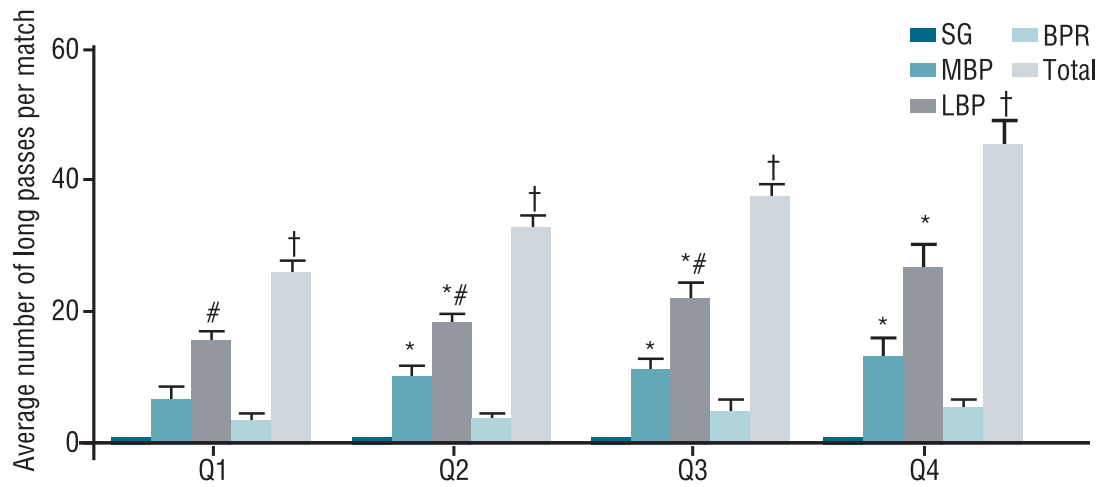

Figure 2. Comparison of the average number of long distance passes and their results per game, stratified by quartiles of total long distance passes per game in the 2014 FIFA World Cup Brazil. ${ }^{*} p<0.05$ compared to the $1^{\text {st }}$ quartile; $\# p<0.05$ compared to the $4^{\text {th }}$ quartile; $\uparrow p<0.05$ between them.

\section{Match Periods Analysis}

Teams performed more long distance passes at the beginning and end of matches (1P15 and 2P45, respectively). The number of SG was low in all periods analyzed. The maximum number of goal opportunities resulting from long distance passes in a match was two kicks (1P30), only one in each period. In the same period (1P30), the MBP rate was lower than in the other periods. $\mathrm{LBP}$ is more accentuated at the beginning of the match and less frequent in the $2 \mathrm{P} 30$ period, when compared to $1 \mathrm{P} 15$ and the $2 \mathrm{P} 45$ periods. BPR was less frequent along the match periods and uncommon in $2 \mathrm{P} 15$ and $2 \mathrm{P} 30$ periods (figure 3 ).

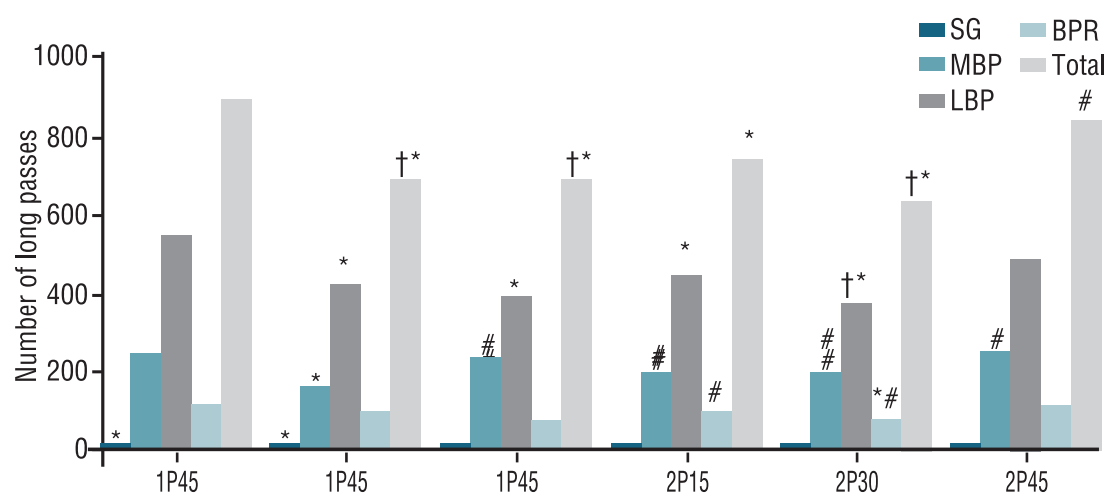

Figure 3. Comparison of the number of long distance passes and their results per match time, each period of 15 minutes of soccer game during the World Cup. Periods were divided into intervals of 15 minutes for the first (1P) and second (2P) game periods. SG: Shots on Goal; MBP: Ball Possession Maintenance; LBP: Loss of Ball Possession; BPR: Ball Possession Recovery. ${ }^{*} p<0.05$ compared to $1 \mathrm{P} 15 ; \# \mathrm{p}<0.05$ compared to $1 \mathrm{P} 30 ; \uparrow \mathrm{p}<0.05$ compared to $2 \mathrm{P} 45$.

\section{Continental Federation Analysis}

Although the Kruskal-Wallis test revealed statistical difference among groups in variables MBP $(p=0.02)$ and TP $(p=0.04)$, the Dunnett's C post hoc test was not sensitive enough to detect such discrepancies. Thus, only a trend towards statistical difference was observed between UEFA and Concacaf teams. Concacaf teams had higher rates than UEFA in these two variables (MBP: $95 \% \mathrm{CI}=-12.89$ to $1.00 ; \mathrm{TP}: 95 \% \mathrm{CI}=-19.08$ to 0.43 ; figure 4$)$. 


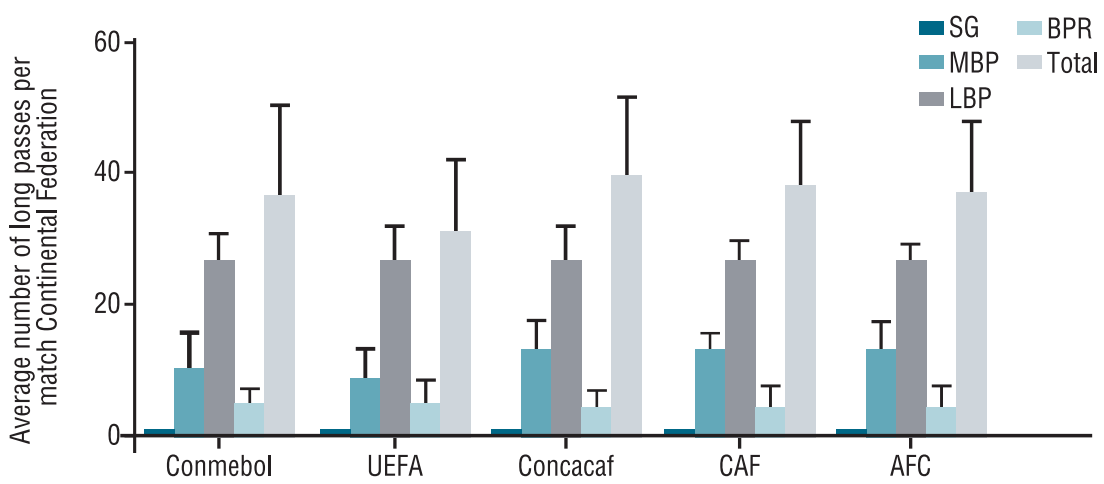

Figure 4. Comparison of the average number of long distance passes and their results per game according on the Continental Federation in the 2014 FIFA World Cup Brazil. SG: Shots on Goal; MBP: Ball Possession Maintenance; LBP: Loss of Ball Possession; BPR: Ball Possession Recovery.

\section{DISCUSSION}

The present study analyzed the effectiveness of long distance passes performed in the 2014 Brazil FIFA World Cup, with a main finding that nearly six of 10 attempts resulted in LBP. In addition, the 4,512 actions performed during competition highlighted little effectiveness that long distance passes were a successful strategy for scoring goals, since fewer than $1 \%$ resulted even in shots on goal. This is in agreement with Hughes and Franks ${ }^{9}$, who conducted a study on the 1990 and 1994 World Cups and found that the most successful teams had significantly higher numbers of goal kicks after longer sequences of passes (more emphasis on ball possession).

Andrade et al. ${ }^{22}$ analyzed 1,035 goals scored in 380 matches of the 2008 Brazilian National Championship - Premier Division, and found that only $1.5 \%$ of the goal assistance came from the defensive field, exclusively in dead ball situations. Anderson and Sally ${ }^{23}$ verified that teams that used long distance passes most in the British Soccer League scored fewer goals and faced the threat of relegation at the end of the season. Añon et al. ${ }^{24}$ showed that, in the final matches of the Champions' League (2011) and the Interclub World Championship (2011), only $19.5 \%$ of the 87 long distance passes were considered correct. The present study indicates a conversion rate of long distance passes into goal kicks of less than $2 \%$ throughout the 64 matches of the 2014 Brazil FIFA World Cup. The aggregated results of these studies make up a strong trend suggesting that long distance passes are not effective for shooting on goal and goal scoring in different levels of the world soccer. Therefore, extending ball possession time appears to be a more efficient alternative strategy for field goal opportunities and a better indicator of a team's success ${ }^{4,9,12,13,14}$.

Of course, shots on goal may not be a team's main objective for using long distance passes; rather, long distance passes may sometimes be efforts to advance faster through the defensive lines ${ }^{25}$ or they may have such other tactical purposes as forcing defenders to protect larger areas of the field. Ortega, Villarejo and Palao ${ }^{25}$ found that winning teams in the Six Nations Rugby Championship used more long distance passes when they 
were in possession of the ball, aimed at breaking through the opponent's defensive lines, moving forward across the field and recovering the ball as close as possible to the goal line. A typical soccer example of this strategy is the Stoke City team, from England, which showed high numbers of long distance passes and an increasing number of goal kicks ${ }^{23}$. Thus, long distance passes may be a better course of action, once a team reaches the point that $40 \%$ of long distance passes are associated with ball possession maintenance or recovery.

Moura et $a 1 .{ }^{26}$ found that the finalist selections of the 2012 UEFA European Championship had greater positional variability of the players than the semi-finalist teams. External midfielders and external defenders obtainable the greatest variability between all positions. Greater variability in tactical behavior may indicate unpredictability to the opponent and the use of the long passes to the sides of the field may cause the team to surprise the opposing team as long as this mechanism is well trained. This study used robust analysis through in soccer ("big data"). This type of analysis, coupled with game analysis, is an important tool for soccer coaches and sports science ${ }^{1,15,27}$.

In the present study, teams that performed fewer long distance passes were less successful in maintaining ball possession. This could be due to the supposedly higher level of specific knowledge of these players, especially concerning the tactical and technical directives of the team ${ }^{4,9,12,13,14}$. Paradoxically, lower-quality or lower-ranking teams may use long distance passes as more perennial strategies ${ }^{23}$. In the present study, there was a proportional relationship between long distance passes and LBP, that is, the more long distance passes, the higher the probability of losing the ball.

Even with statistical difference in goal kicks in 1P30 compared to other periods, the number of shots resulting from long distance passes in this period was only two. This result reinforces the prior discussion of the ineffectiveness of long distance passes for increasing goal shots ${ }^{4,9,12,13,14}$.

We found that teams lost ball possession even more frequently when they performed long distance passes in the first and last 15 minutes of the game. The explanation for this can be twofold: excessive caution at the beginning of the game and time pressure at the end of it. Scoring a goal is a rare event in a soccer match ${ }^{23}$, and a goal scored or conceded in the very first minutes alters the entire context of the game. Notwithstanding, at the end of the game, long distance passes once again appeared as a more effective strategy in relation to short passes, due to the need to reach the opponent's goal quickly.

Another factor that can influence long distance passes per period are the player substitutions coaches make through the match ${ }^{28}$. As there are more substitutions between the $60^{\text {th }}$ and $85^{\text {th }}$ minute of the match, particularly from offensive teams ${ }^{28}$, opportunities for long distances passes are greater between during certain other periods.

In this study, teams from different International Federations showed homogeneity with respect to variables studied, regardless of culture and 
game philosophy. Even though statistical tests could not verify differences, UEFA teams trended to make fewer long distance passes and lose fewer ball possessions than Concacaf teams. Current European game style is oriented to praise ball possession rather than direct playing, and to keep line compaction in offensive actions ${ }^{12,23,24,29,30}$.

In this study, the specific field zone that long distance passes targeted was not verified, which could be considered as a limitation. In the same way, the present study did not investigate the decision-making quality of long distance passes. However, it is important to highlight that these factors would only enrich data, and were not determinant for the results obtained. Such criterion may be used in future studies aimed at investigating the effectiveness of long distance passes, increasing the amount of information on this variable.

Another limitation of the study was the non-performance of the interrater analysis, considering that only one individual analyzed the games. However, this does not methodically impede the study, therefore, not compromising the results obtained in the research, since the objective of the study was not to validate the method but to verify the impact of the long passes in high level soccer matches. Inter-rater analysis is suggested in future studies.

This study shows that it is important to engage in a broader teachinglearning process for improving soccer play. Specific variables like long distance passes should not be considered in isolation. Their use with no preparation or appropriate context appears to be an ineffective strategy, since the majority of outcomes are the loss of ball possession. However, coaches should take into account the context of daily training routines, characteristics of players, and game philosophy. Thereby, long distance passes may become a reasonable strategy for maximizing the overall performance of both players and teams in given circumstances.

\section{CONCLUSIONS}

The present study found that: a) long distance passes have low effectiveness, since they promote a high rate of loss of ball possession, and rarely create shot on goal opportunities; b) there is a greater prevalence of both long distance passes executed and the loss of ball possession, resulting from long distance passes, in the initial and final $15 \mathrm{~min}$ of the game; c) the quantity of long distance passes and their results are similar among the teams, regardless of Continental Federation.

\section{Acknowledgments}

The authors of this research thank the Commission for the Improvement of Higher Education Personnel - CAPES and the Foundation for Support to Research and Technological Innovation of the State of Sergipe - FAPITEC / SE for funding the study from a research incentive grant. 


\section{REFERENCES}

1. Rein R, Memmert D. Big data and tactical analysis in elite soccer: future challenges and opportunities for sports science. Springerplus 2016;5(1):1420-2.

2. González-Víllora S, Serra-Olivares J, Pastor-Vicedo J, Costa I. Review of the tactical evaluation tools for youth players, assessing the tactics in team sports: football. Springerplus 2015;4(1):663-79.

3. Costa I, Silva J, Greco P, Mesquita I. Princípios Táticos do Jogo de Futebol: conceitos e aplicação. Motriz: J Phys Ed 2009;15(3):657-68.

4. Lago C, Martin R. Determinants of possession of the ball in soccer. J Sports Sci 2007;25(9):969-74.

5. Mota G, Thiengo C, Gimenes S, Bradley P. The effects of ball possession status on physical and technical indicators during the 2014 FIFA World Cup Finals. J Sports Sci 2016;34(6):493-500.

6. Barreira D, Garganta J, Castellano J, Machado J, Anguera M. How elite-level soccer dynamics has evolved over the last three decades? Input from generalizability theory. Cuad Psicol Deporte 2015;15(1):51-62.

7. Barreira D, Garganta J, Castellano J, Prudente J, Anguera M. Evolución del ataque en el fútbol de élite entre 1982 y 2010: Aplicación del análisis secuencial de retardos. Rev Psicol Deporte 2014;23(1):139-46.

8. Reep C, Benjamin B. Skill and Chance in Association Football. J R Stat Soc 1968;131(1):581-85.

9. Hughes M, Franks I. Analysis of passing sequences, shots and goals in soccer. J Sports Sci 2005;23(5):509-14.

10. Lago-Peñas C, Gómez-Ruano M, Megías-Navarro D, Pollard R. Home advantage in football: Examining the effect of scoring first on match outcome in the five major European leagues. Int J Perf Anal Sport 2016;16(1):411-21.

11. Liu H, Gomez M, Gonçalves B, Sampaio J. Technical performance and match-tomatch variation in elite football teams. J Sports Sci 2016;34(6):509-18.

12. Liu H, Gomez M, Lago-Peñas C, Sampaio J. Match statistics related to winning in the group stage of 2014 Brazil FIFA World Cup. J Sports Sci 2015;33(12):1205-13.

13. Lago-Peñas C, Lago-Ballesteros J. Game location and team quality effects on performance profiles in professional soccer. J Sports Sci Med 2011;10(3):465-71.

14. Lago-Peñas C, Dellal A. Ball Possession Strategies in Elite Soccer According to the Evolution of the Match-Score: the Influence of Situational Variables. J Hum Kinet 2010;25(1):93-100.

15. Garganta J. A análise da performance nos jogos desportivos. Revisão acerca da análise do jogo. Rev Port Cien Desp 2001;1(1):57-64.

16. Bayer C. O ensino dos desportos colectivos. Portugal: Dinalivro; 1994.

17. Costa I, Garganta J, Greco P, Mesquita I, Maia J. Sistema de avaliação táctica no Futebol (FUT-SAT): Desenvolvimento e validação preliminar. Motri 2011;7(1):6984.

18. Robinson G, P O'Donoghue. A weghted kappa statistic for reliability testing in performance analysis of sport. Int J Perform Anal Sport 2007;7(1):12-9.

19. Cohen J. Statistical Power for Behavioral Sciences. New York, USA: Academic Press; 1988.

20. Dancey C, Reidy J. Estatística sem matemática para psicologia. Porto Alegre, Brasil: Penso; 2013.

21. Archive with matches data 2014 FIFA World Cup Brazil. FIFA World Cup: Brazil. 2014; Available from: http://www.fifa.com/worldcup/archive/brazil2014/ matches/index.html [2015 jun 30].

22. Andrade M, Santo L, Andrade A, Oliveira G. Análise dos gols do Campeonato Brasileiro de 2008 - Série A. Rev Bras Ciênc Esporte 2015;37(1):49-55.

23. Anderson C, Sally, D. Os números do jogo: por que tudo o que você sabe sobre futebol está errado. São Paulo, Brasil: Paralela; 2013. 
24. Añon I, Lizana C, Calazans E, Machado J, Costa I, Scaglia A. Performance da equipe do Barcelona e seus adversários nos jogos finais da Champions League e da Copa do Mundo de Clubes FIFA 2010. Rev Andal Med Deporte 2014;7(1):13-20.

25. Ortega E, Villarejo D, Palao J. Differences in game statistics between winning and losing rugby teams in the Six Nations Tournament. J Sports Sci Med 2009;8(4):523-7.

26. Moura F, Santana J, Vieira N, Santiago P, Cunha S. Analysis of Soccer Players' Positional Variability During the 2012 UEFA European Championship: A Case Study. J Hum Kinet 2015;47(1):225-36.

27. Malta P, Travassos B. Caraterização da transição defesa-ataque de uma equipa de Futebol. Motri 2014;10(1):27-37.

28. Bradley P, Lago-Peñas C, Rey E. Evaluation of the Match Performances of Substitution Players in Elite Soccer. Int J Sports Physiol Perform 2014;9(3):415-24.

29. Barreira D, Garganta J, Guimarães P, Machado J, Anguera M. Ball recovery patterns as a performance indicator in elite soccer. J Sports Eng Technol 2014;228(1):61-72.

30. Machado J, Barreira D, Garganta J. Eficácia ofensiva e variabilidade de padrões de jogo em futebol. Rev Bras Educ Fís Esporte 2013;27(4):667-77.

\section{CORRESPONDING AUTHOR}

Marcos Antônio Mattos dos Reis Rua Professora Zely Guedes Ximenes, $n^{\circ}$ 30, Bairro Aeroporto. CEP 49037-530, Aracaju, SE. Brasil E-mail:mamreis91@gmail.com 